Research Article

\title{
Effect of hemodialysis session on acute changes in inflammatory and cardiovascular risk biomarkers
}

\section{Bernardo-Alio Lavín Gómez*, María-Teresa García Unzueta Armando-Raúl Guerra Ruiz ${ }^{1}$, Sonia Pérez San-Martín ${ }^{1}$, Ana Berja ${ }^{1}$, Natalia Fañanás Rodríguez ${ }^{1}$, Sara Díez Espejo ${ }^{1}$ and Domingo González-Lamuño Leguina²}

${ }^{1}$ Clinical Biochemistry Department, Marqués de Valdecilla University Hospital. Valdecilla Health Research Institute (IDIVAL), Santander, Spain

${ }^{2}$ Pediatric Department, Marqués de Valdecilla University Hospital. Valdecilla Health Research Institute (IDIVAL), Santander, Spain

\section{Abstract}

Background: Inflammation is associated with enhanced cardiovascular risk profile and increased cardiovascular mortality in end-stage kidney disease patients undergoing hemodialysis. Mechanisms of activated acute phase reaction in patients on chronic hemodialysis remain to be identified. As successful treatment of the inflammatory condition in these patients may improve long-term survival, we studied potential changes in different inflammatory biomarkers of cardiovascular risk in end-stage kidney disease patients after a mid-week hemodialysis session.

Methods: Inflammatory biomarkers of cardiovascular risk (cystatin- $\mathrm{C}$, homocysteine, C-reactive protein, procalcitonin, pentraxin-3, serum amyloid-A) and atherogenic plasma lipoproteins (Lipoprotein(a), cholesterol low and high density lipoproteins) were studied in 21 end-stage kidney disease patients previously and after a mid-week hemodialysis session.

Results: We found a significant reduction in serum levels of low molecular weight molecules: cystatin-C (5.56 to $1.85 \mathrm{mg} / \mathrm{L}, 66.73 \%, p<0.001)$, homocysteine $(22.85$ to $13.25 \mu \mathrm{mol} / \mathrm{L}, 42.01 \%$, $p<0.001)$ and procalcitonin $(0.788$ to $0.457 \mathrm{ng} / \mathrm{mL}, 42.01 \%, p<0.001)$. Large molecules as C-reactive protein $(9.70$ to $9.90 \mathrm{mg} / \mathrm{L}, 2.06 \%, p=0.022)$ and pentraxin-3 $(1.67$ to $4.28 \mathrm{ng} / \mathrm{mL}$, $156 \%, p<0.001)$ increased, but serum amyloid-A decreased $(15.90$ to $12.70 \mathrm{mg} / \mathrm{L}, 20.13 \%, p<$ 0.05). There was no change in Lipoprotein (a) levels.

Conclusion: Pentraxin-3 was a more specific inflammatory vascular marker than C-reactive protein, and the best inflammatory marker associated with hemodialysis. Homocysteine, procalcitonin and the other small proteins could be released and removed during hemodialysis session. Further studies are needed to understand the behavior and significance of these markers after successive hemodialysis.

\section{More Information}

*Address for Correspondence: Bernado A. Lavín Gómez, Clinical Biochemistry Department, Marqués de Valdecilla University Hospital. Valdecilla Health Research Institute (IDIVAL), Santander, Spain, Tel: 0034.942202720; Fax: 0034.942205296; Email: balavin@humv.es; aliolaving@yahoo.es

\section{Submitted: 31 December 2019}

Approved: 08 January 2020

Published: 09 January 2020

How to cite this article: Gómez BAL, Unzueta MTG, Ruiz ARG, San-Martín SP, Berja A, et al. Effect of hemodialysis session on acute changes in inflammatory and cardiovascular risk biomarkers. J Cardiol Cardiovasc Med. 2020; 5: 004-0010.

DOI: dx.doi.org/10.29328/journal.jccm.1001077 ORCiD: orcid.org/0000-0001-7279-7643

Copyright: @ 2020 Gómez BAL, et al. This is an open access article distributed under the Creative Commons Attribution License, which permits unrestricted use, distribution, and reproduction in any medium, provided the original work is properly cited.

Keywords: Biological-markers; Hemodialysis; Inflammation; Pentraxin-3 protein; Procalcitonin; Serum amyloid-A

Abbreviations: CRP: C-Reactive Protein; PosHD: After Hemodialysis; PreHD: Before Hemodialysis; PTX3: Pentraxin-3; SAA: Serum Amyloid-A

\section{(W) Check for updates}

๑) open Access

\section{Introduction}

Cardiovascular disease is the main cause of premature death in Chronic Kidney Disease patients [1].

Inflammation is associated with enhanced cardiovascular risk profile and increased cardiovascular mortality in hemodialysis patients. Many patients in end-stage kidney disease exhibits an activated acute phase response, characterized by an increase of C-reactive protein (CRP) and serum amyloid-A (SAA). These acute phase proteins are independent predictor of overall and cardiovascular mortality in hemodialysis patients, besides age, low body mass index, presence of diabetes, pre-existing cardiovascular disease, and male gender [2].

The search for a more effective risk stratification has generated predictive models [1,3-5], based on reappraisal of classical and emerging markers of inflammation and cardiovascular risk. C-reactive protein (CRP), homocysteine, and lipoprotein(a)), should be included in the assessment of global cardiovascular risk. Other inflammatory proteins like 
pentraxin-3 (PTX3), serum amyloid-A (SAA), procalcitonin and cystatin-C (CysC), could improve estimation of cardiovascular risk. PTX3, a 450kDa molecule secreted by neutrophils and the vascular wall cells after cytokine stimulation (interleukin-1, TNF- $\alpha$ ), may be a novel biomarker for inflammatory cardiovascular Disease [6]. SAA, a polymer of 85 to $200 \mathrm{KDa}$ is an acute phase reactant secreted by liver after stimulation of different cytokines. It converts HDL into a proatherogenic lipoprotein by displacing apolipoprotein-A1 [7]. SAA is also an immunomodulator of inflammation and has a role in the pathogenesis of amyloidosis [8]. Procalcitonin (14,5KDa) has hypotensive effects and protects renal parenchyma against cell apoptosis and fibrosis in acute pyelonephritis [9]. Procalcitonin basal levels are increased in chronic kidney disease due to reduced renal clearance [10]. Cystatin-C $(13 \mathrm{KDa})$ is synthesized by multiple cell types and has inhibitory activity against cysteine proteases. It is filtered by glomerulus and catabolized by proximal tubular cells. High levels of serum Cystatin- $\mathrm{C}$ indicate reduced glomerular filtration rates [11] and could be a predictor of death in coronary patients with normal renal function [12]. Homocysteine, a sulfurcontaining amino acid methionine derivative, circulates free and bound to proteins in blood [13]. Free homocysteine is filtered at glomerulus and reabsorbed in renal tubules. Hyperhomocysteinemia is an independent cardiovascular risk factor because of its oxidizing capacity [14]. Lipoprotein(a) is a low density lipoprotein with a similar composition of lipids and apolipoprotein-B100 as LDL cholesterol, but with an additional apolipoprotein(a). High concentrations are considered independent risk factor for development of coronary heart disease [15]. Mechanisms of activated acute phase reaction in patients on chronic hemodialysis remain to be identified and a successful treatment of the inflammatory condition may improve long-term survival in these patients.

The aim of this study was to examine the impact of the dialysis procedure on the removal or generation of classical and emerging biomarkers of acute inflammatory response and cardiovascular risk in 21 end-stage kidney disease patients after a high-flux HD and estimate cardiovascular risk in healthy controls and end-stage kidney disease following Adult Treatment Panel-III ${ }^{3}$ and International Atherosclerosis Society [5] guidelines.

\section{Methodology (subjects and methods)}

\section{Ethical considerations}

This research was conducted in accordance with the Helsinki Declaration and the protocol was approved by the Ethics Committee of Hospital Universitario Marqués de Valdecilla - IDIVAL, Santander, Spain. Patients gave written informed consent, and healthy controls gave verbal consent for the sample extraction.

\section{Patients}

We selected 21 end-stage kidney disease patients in hemodialysis from the HD Unit of Nephrology Department of Valdecilla University Hospital; and 69 usual blood donors, as healthy controls from the Blood and Tissue Bank of Cantabria (Fundación Marqués de Valdecilla, Santander, Spain). Clinical and demographic data (age, sex, blood pressure, smoking, diabetes, personal and family history of ischemic heart disease, dyslipidemia, antihypertensive and lipid lowering therapy) were collected from medical register. Blood samples (serum and EDTA-plasma) from healthy controls and from the 21 patients, were collected immediately before (preHD) and after (posHD) of a mid-week session with biocompatible and high-permeability membranes (Cordiax 1.8 Fresenius; AN69ST-Nephral). Exclusion criteria were: children $(<18$ years old), less than one month replacement therapy HD, acute infection, and positive Human Immunodeficiency Virus, Hepatitis B Virus or Hepatitis C Virus at time of extraction of the samples.

\section{Methods}

Plasma and serum samples were obtained by centrifugation at $1500 \mathrm{~g}$, aliquoted and frozen at $-80^{\circ} \mathrm{C}$ in lower than 30 minutes after blood collection. Creatinine, urea, albumin, triglycerides and total cholesterol were determined in Dimension RXL ${ }^{\circledR}$ (Siemens Healthcare Diagnostics, Newark, United States). HDL-cholesterol (HDL) after precipitation of non-HDL lipoproteins with phosphotungstic-magnesium acid of Biosystems ${ }^{\circledR}$ (Barcelona, Spain) and supernate cholesterol was measured by slightly modified CHOD-PAP method (from Biosystems in a Dimension $\mathrm{RXL}^{\circledR}$ ). LDL-cholesterol was calculated using the Friedewald formula (LDLcalc). The CRP, SAA, Cystatin-C, homocysteine, apolipoprotein-A1 (apoA1), apolipoprotein-B100 (apoB) and lipoprotein(a) were quantified by immunonephelometry in BNII-System $^{\circledR}$ (Siemens Healthcare Diagnostics, Germany). Procalcitonin was analyzed by time resolved amplified cryptate emission immunoassay technology (Kryptor ${ }^{\circledR}$ Brahms-sensitive Procalcitonin assay: Brahms, Hennigsdorf, Germany) and plasma PTX3 levels by ELISA (Human Pentraxin 3/TSG-14 ELISA, Perseus Proteomics ${ }^{\circledR}$, Tokyo, Japan). Hemodialysis samples (preHD, posHD) from each patient were analyzed in the same series, but not consecutively, to avoid inter assay variations. Creatinine and urea were analyzed as a reference to evaluate changes of similar size molecules (small size) during hemodialysis. Albumin was also analyzed to assess large ones. In healthy controls, classical and emerging biomarkers for cardiovascular risk calculation were determined.

Cardiovascular risk was estimated in healthy controls and end-stage kidney disease, following Adult Treatment PanelIII $^{3}$ and International Atherosclerosis Society [5] guidelines, in order to evaluate changes in classification of risk after including accepted emerging cardiovascular risk factors.

\section{Statistical analysis}

Non parametric tests were used because of sample size although all biomarkers, except PTX3, showed normal 
distribution after applying the Kolmogorov-Smirnov test. Comparisons between posHD and preHD samples were performed using the Wilcoxon test for analysis of differences independent samples related. Statistical significance of $p$ $<0.050$ was considered. All descriptive analysis data are shown as median and confidence interval of $95 \%$. The percent change in biomarkers after hemodialysis was calculated as follows: median (preHD - posHD)/preHD in \%. The statistical treatment of the data was performed with MedCalc.11.6.0.0 Software ${ }^{\circledR}$ (MedCalc, Mariakerke, Belgium).

\section{Results}

Demographic and physical characteristics of patients and the healthy controls are shown in tables $1 \mathrm{a}, 1 \mathrm{~b}$. Results of clinical data, classical biomarkers and emerging risk factors are analyzed, before and after a mid-week high flux hemodialysis session in patients are detailed in tables 2,3.

We observed a significant reduction in small molecules during the high flux hemodialysis. Cystatin-C decreased

Table 1a: Demographic and clinical data from patients in hemodialysis $(n=21)$.

\begin{tabular}{|c|c|}
\hline Sex (men/women) & $14 / 7$ \\
\hline Age (years)* & $63.0(50.5-75.0)$ \\
\hline Dialysis vintage(years)* & $2.1(1.6-3.2)$ \\
\hline Sessions per week & $\begin{array}{c}3 \text { (Monday, Wednesday', Friday; or Tuesday, } \\
\text { Thursday }{ }^{\uparrow} \text {, Saturday) }\end{array}$ \\
\hline High permeability membranes & $\begin{array}{l}15 \text { Cordiax } 1.8 \text { Fresenius; } \\
6 \text { AN69ST-Nephral }\end{array}$ \\
\hline Blood Flow Hemodialysis (ml/min)* & $341(329-352)$ \\
\hline Vascular access & $\begin{array}{l}15 \text { Internal arteriovenous fistula; } \\
6 \text { Tesio central catheter }\end{array}$ \\
\hline Heparin (UI)* & $60.0(55.6-70.0)$ \\
\hline Time dialysis session (hours)* & $4.1(3.9-4.2)$ \\
\hline Weight loss $(\mathrm{Kg})^{\star}$ & $2.0(1.2-2.7)$ \\
\hline $\begin{array}{c}\text { Weight change (\%) [(preHD-posHD)/ } \\
\text { preHD] }\end{array}$ & $3.5(1.4-4.1)$ \\
\hline $\begin{array}{l}\text { Systolic Blood Pressure preHD } \\
\qquad(\mathrm{mmHg})^{\star}\end{array}$ & $135(112-148)$ \\
\hline $\begin{array}{l}\text { Diastolic Blood Pressure preHD } \\
\qquad(\mathrm{mmHg})^{\star}\end{array}$ & $75(71-80)$ \\
\hline $\begin{array}{l}\text { Hypertensive patients/with } \\
\text { antihypertensive treatment }\end{array}$ & $13 / 13(62 \%)$ \\
\hline Diabetic patients & $9(43 \%)$ \\
\hline Smokers & $6(29 \%)$ \\
\hline Personal history of $\mathrm{CHD}$ & $8(38 \%)$ \\
\hline Lipid-lowering drugs & $2(10 \%)$ \\
\hline
\end{tabular}

*median (IC95\%). ${ }^{\dagger}$ Morning mid-week session. PreHD: Before-Hemodialysis. PosHD: After-Hemodialysis. CHD: Coronary Heart Disease

Table 1b: Characteristics of healthy control group $(n=69)$.

\begin{tabular}{|c|c|}
\hline \multicolumn{1}{|c|}{ Control group } \\
\hline Sex (men/women) & $37 / 32$ \\
\hline Age (years)* & $42.0(28.0-56.0)$ \\
\hline Systolic Blood Pressure $(\mathrm{mmHg})^{\star}$ & $130(120-137)$ \\
\hline Diastolic Blood Pressure $(\mathrm{mmHg})^{*}$ & $78(76-80)$ \\
\hline Hypertensive patients /with antihypertensive treatment & $34 / 34(49 \%)$ \\
\hline Diabetics & $11(16 \%)$ \\
\hline Smokers & $8(12 \%)$ \\
\hline Personal history of CHD & $5(7 \%)$ \\
\hline Lipid-lowering drugs & $0(0 \%)$ \\
\hline *median (IC95\%). CHD: Coronary Heart Disease & \\
\hline
\end{tabular}

Tabla 2: Biological markers in healthy control group.

\begin{tabular}{|c|c|}
\hline Creatinine $(\mathrm{mg} / \mathrm{dL})$ & $0.91(0.88-0.95)$ \\
\hline Urea $(\mathrm{mg} / \mathrm{dL})$ & $36.1(35-37)$ \\
\hline Cystatin-C(mg/dL) & $0.78(0.74-0.83)$ \\
\hline Albumin $(\mathrm{g} / \mathrm{dL})$ & $4.2(4.1-4.2)$ \\
\hline Procalcitonin $(\mathrm{ng} / \mathrm{mL})$ & $0.028(0.022-0.032)$ \\
\hline CRP $(\mathrm{mg} / \mathrm{L})$ & $1.40(1.20-2.10)$ \\
\hline PTX3 $(\mathrm{ng} / \mathrm{mL})$ & $0.54(0.33-0.62)$ \\
\hline SAA $(\mathrm{mg} / \mathrm{L})$ & $3.10(2.90-3.53)$ \\
\hline Homocysteine $(\mu \mathrm{mol} / \mathrm{L})$ & $12.20(11.03-14.02)$ \\
\hline Total cholesterol $(\mathrm{mg} / \mathrm{dL})$ & $200.00(193.77-215.23)$ \\
$(\mathrm{mmol} / \mathrm{L})$ & $5.18(5.02-5.57)$ \\
\hline HDL $(\mathrm{mg} / \mathrm{dL})$ & $51.00(47.54-57.00)$ \\
$(\mathrm{mmol} / \mathrm{L})$ & $1.32(1.23-1.40)$ \\
\hline Apolipoprotein-A1 $(\mathrm{mg} / \mathrm{dL})$ & $158.00(153.00-167.46)$ \\
\hline LDLcalc $(\mathrm{mg} / \mathrm{dL})$ & $128.60(119.71-137.89)$ \\
$(\mathrm{mmol} / \mathrm{L})$ & $3.33(3.10-3.57)$ \\
\hline apolipoprotein-B100 $(\mathrm{mg} / \mathrm{dL})$ & $105.00(96.00-111.46)$ \\
\hline Lipoprotein(a) $(\mathrm{mg} / \mathrm{dL})$ & $21.00(11.00-23.00)$ \\
\hline Triglycerides $(\mathrm{mg} / \mathrm{dL})$ & $101.00(87.77-113.00)$ \\
\hline
\end{tabular}

Values: Median (IC95\% rank); CRP: C-Reactive Protein; HDL: Cholesterol High Density Lipoprotein by lipoprotein precipitation

LDLcalc: Cholesterol Low Density Lipoproteins by Friedewald formula

SAA: Serum amyloid-A; PTX-3: Pentraxin-3

from 5.56 to $1.85 \mathrm{mg} / \mathrm{L}$ (percent change: $66.73 \%, p<0.001$ ), homocysteine from 22.85 to $13.25 \mu \mathrm{mol} / \mathrm{L}(42.01 \%, p<0.001)$ and Procalcitonin from 0.788 to $0.457 \mathrm{ng} / \mathrm{mL},(42.01 \%, p<$ 0.001 ) as occurred with small solutes like urea (from 115 to $34 \mathrm{mg} / \mathrm{dL}, 70.43 \%, p<0.001$ ) and creatinine (from 7.90 to $2.80 \mathrm{mg} / \mathrm{dL}, 64.56 \%, p<0.001$ ).

On the other hand, we detected a significant increase in high molecular weight solutes: CRP increased from 9.70 to $9.90 \mathrm{mg} / \mathrm{L}(2.06 \%, p=0.022)$ and PTX3 from 1.67 to 4.28 $\mathrm{ng} / \mathrm{mL}(156 \%$ increase, $p<0.001)$. Total cholesterol also significantly increased from 173 to $194 \mathrm{mg} / \mathrm{dL}(12.14 \%, p=$ $0.002)$, and HDL ( $\geq 175 \mathrm{KDa}$ ) and apoA1 increased $26.30 \%$ ( $p$ $=0.007)$ and $2.42 \%(p=0.014)$ respectively. LDL $(\approx 550 \mathrm{KDa})$ increased $16.76 \%(p=0.064)$ and apolipoprotein-B100 a $19.52 \%(p=0.002)$. Triglycerides showed a non-significant up-trend (108 to $122 \mathrm{mg} / \mathrm{dL}, 12.96 \%, p=0.082$ ). We did not observed substantial changes in lipoprotein(a) (17.05 to $16.95 \mathrm{mg} / \mathrm{dL}, 0.59 \%, p=0.829$ ). Nevertheless SAA, despite being a high molecular weight molecule, suffered a marked reduction (15.90 to $12.70 \mathrm{mg} / \mathrm{L}, 20.13 \%, p<0.05)$. Urea, albumin and HDL reached levels similar to normal population after a hemodialysis session of 4 hours in which excess volume is eliminated (median $2 \mathrm{~kg}$, weight significantly decreased by $3.5 \%, p<0.001$; Table 3 ). Other parameters such as creatinine, cystatin-C, homocysteine and Procalcitonin were removed but did not reach the normal levels established for healthy people.

Serum levels of emerging risk factors (CRP, Lipoprotein(a), homocysteine) before a mid-week hemodialysis session and in healthy controls are shown in table 4.

Cardiovascular risk was calculated with classical major cardiovascular risk factors following Adult Treatment Panel-III guidelines and also with emerging risk factors following International Atherosclerosis Society guidelines. 
Table 3: Parameters analyzed in pre- and post-hemodialysis samples in a mid-week hemodialysis session.

\begin{tabular}{|c|c|c|c|c|c|c|}
\hline \multirow[t]{2}{*}{$(n=21)$} & \multicolumn{2}{|c|}{ PreHD } & \multicolumn{2}{|c|}{ PosHD } & \multirow{2}{*}{$\begin{array}{c}\text { Wilcoxom } \\
p\end{array}$} & \multirow{2}{*}{$\begin{array}{c}\text { (PreHD - posHD)/preHD } \\
\% \text { change }\end{array}$} \\
\hline & median & IC95 rank & median & IC95 rank & & \\
\hline Creatinine (mg/dL) & 7.90 & $7.27-8.94$ & 2.80 & $2.51-3.19$ & 0.000 & 64.56 \\
\hline Urea (mg/dL) & 115.00 & $98.92-141.80$ & 34.00 & $28.00-43.44$ & 0.000 & 70.43 \\
\hline Cystatin-C (mg/L) & 5.56 & $4.98-6.01$ & 1.85 & $1.58-2.25$ & 0.000 & 66.73 \\
\hline Albumin (g/dL) & 3.50 & $3.10-3.60$ & 3.60 & $3.11-4.20$ & 0.002 & -2.86 \\
\hline Procalcitonin (ng/mL) & 0.788 & $0.485-0.989$ & 0.457 & $0.274-0.588$ & 0.000 & 42.01 \\
\hline $\mathrm{CRP}(\mathrm{mg} / \mathrm{L})$ & 9.70 & $7.01-16.43$ & 9.90 & $7.05-19.74$ & 0.022 & -2.06 \\
\hline PTX3 (ng/mL) & 1.67 & $1.13-2.27$ & 4.28 & $2.66-6.97$ & 0.000 & -156.29 \\
\hline SAA (mg/L) & 15.90 & $6.76-37.72$ & 12.70 & $4.98-35.33$ & 0.000 & 20.13 \\
\hline Homocysteine $(\mu \mathrm{mol} / \mathrm{L})$ & 22.85 & $18.10-25.80$ & 13.25 & $9.90-14.48$ & 0.000 & 42.01 \\
\hline $\begin{array}{l}\text { Total cholesterol }(\mathrm{mg} / \mathrm{dL}) \\
(\mathrm{mmol} / \mathrm{L})\end{array}$ & $\begin{array}{c}173.00 \\
4.48\end{array}$ & $\begin{array}{c}125.72-210.96 \\
3.26-5.46\end{array}$ & $\begin{array}{c}194.00 \\
5.02\end{array}$ & $\begin{array}{c}157.96-229.44 \\
4.09-7.76\end{array}$ & 0.002 & -12.14 \\
\hline $\begin{array}{l}\mathrm{HDL}(\mathrm{mg} / \mathrm{dL}) \\
(\mathrm{mmol} / \mathrm{L})\end{array}$ & $\begin{array}{c}47.33 \\
1.23\end{array}$ & $\begin{array}{l}33.26-62.44 \\
0.86-1.62\end{array}$ & $\begin{array}{c}59.78 \\
1.55\end{array}$ & $\begin{array}{c}41.08-66.92 \\
1.06-1.73\end{array}$ & 0.007 & -26.30 \\
\hline apo A1 (mg/dL) & 124.00 & $104.37-138.44$ & 127.00 & $115.68-153.44$ & 0.014 & -2.42 \\
\hline $\begin{array}{l}\operatorname{LDLcalc}(\mathrm{mg} / \mathrm{dL}) \\
\quad(\mathrm{mmol} / \mathrm{L})^{*}\end{array}$ & $\begin{array}{c}90.80 \\
2.35\end{array}$ & $\begin{array}{c}63.11-122.35 \\
1.63-3.17\end{array}$ & $\begin{array}{c}106.02 \\
2.75\end{array}$ & $\begin{array}{l}69.21-126.30 \\
1.79-3.27\end{array}$ & 0.064 & -16.76 \\
\hline Apolipoprotein-B100 (mg/dL) & 79.90 & $65.83-104.44$ & 95.50 & 72.23-110.44 & 0.002 & -19.52 \\
\hline Lipoprotein(a) (mg/dL) & 17.05 & $9.79-26.56$ & 16.95 & $11.12-22.00$ & 0.829 & 0.59 \\
\hline 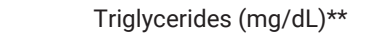 & 108.00 & $97.24-147.52$ & 122.00 & $92.40-192.76$ & 0.082 & -12.96 \\
\hline Weight (Kg) & 72.3 & $61.1-81.1$ & 69.6 & $60.3-78.5$ & 0.000 & 3.5 \\
\hline
\end{tabular}

Table 4: Positive emerging risk factors in healthy controls and end-stage kidney disease patients before a mid-week hemodialysis session.

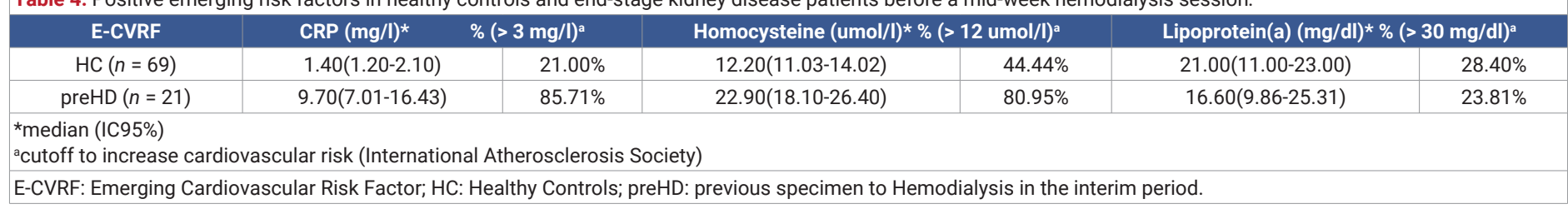

Table 5: Cardiovascular risk estimated by applying major risk factor (Adult Treatment Panel III) compared to cardiovascular risk estimated with emerging risk factors by International Atherosclerosis Society in healthy control population and in hemodialysis patients before a mid-week session.

\begin{tabular}{|c|c|c|c|c|c|c|c|c|}
\hline CVR & \multicolumn{2}{|c|}{ Low (\%) } & \multicolumn{2}{|c|}{ Intermediate (\%) } & \multicolumn{2}{|c|}{ High (\%) } & \multicolumn{2}{|c|}{ Very High (\%) } \\
\hline with - CVRF & M- & E- & $M-$ & E- & M- & E- & $M-$ & E- \\
\hline $\mathrm{HC}$ & 34.78 & $\begin{array}{c}30.43 \\
(-4.35 \%)\end{array}$ & 27.54 & $\begin{array}{c}28.99 \\
(+1.45 \%)\end{array}$ & 37.68 & $\begin{array}{c}30.43 \\
(-7.25 \%)\end{array}$ & $---\star$ & $\begin{array}{c}10.14 \\
(+10.14 \%)\end{array}$ \\
\hline preHD & 23.81 & $\begin{array}{c}4.78 \\
(-19.03 \%)\end{array}$ & 4.76 & $\begin{array}{c}23.80 \\
(+19.04 \%)\end{array}$ & 71.43 & $\begin{array}{c}14.28 \\
(-57.15 \%)\end{array}$ & $---*$ & $\begin{array}{c}57.14 \\
(+57.14 \%)\end{array}$ \\
\hline
\end{tabular}

CVR: Cardiovascular Risk; CVRF: Risk Factor Of Cardiovascular Disease; M: Major; E: Emerging; HC: Healthy Controls; preHD: specimen previous to a mid-week Hemodialysis session.

(*) Adult Treatment Panel III and previous Guidelines do not calculated "very high risk" while new European Guidelines and International Atherosclerosis Society including this new CVR stage. The change (in \%) of CVR after applying the E-CVRF is shown in brackets.

Biological markers could explain the excess of CVR that end-stage kidney disease patients have.

A large increase of cardiovascular risk was observed when emerging risk factor of cardiovascular disease were taken into consideration. The increase in cardiovascular risk was higher in end-stage kidney disease than in healthy controls. $19.03 \%$ from $23.81 \%$ of end-stage kidney disease patients with low cardiovascular risk became intermediate risk level; and $57.14 \%$ from $71.43 \%$ of patients with high cardiovascular risk passed to a very high risk level when emerging risk factor of cardiovascular disease were taken into account. Differences between two types of computational models to calculate cardiovascular risk are shown in table 5.

\section{Discussion}

This research shows inflammation biomarkers have different behaviour in patients undergoing hemodialysis mainly according their differences in molecular weight. These changes could be associated with enhanced cardiovascular risk profile and the increased cardiovascular mortality in hemodialysis patients.

Hemodialysis removes excess of volume and free toxic plasmatic molecules of low molecular weight, in patients with end-stage kidney disease. As expected, significant decreases are observed in small molecules like urea, creatinine and cystatin- $\mathrm{C}$, whose clearance depends on the glomerular filtration rate; however, other molecules of similar size do not have the same behavior. Homocysteine is less likely to decrease because it circulates in the plasma in a free and protein-bound 
form preventing its filtration and leading to possible adverse vascular effects [13]. Procalcitonin, another small molecule, increased in predialysis samples. It is an indirect marker of infection and micro-inflammation for biocompatibility of hemodialysis membranes in patients without infection [16] However procalcitonin could be released during the dialysis process, by TNF- $\alpha$ induction that is also increased, and filtered during HD [17]. In a single hemodialysis session it is not a useful marker of low grade inflammation but long term high levels of procalcitonin may be useful as a new cardiovascular marker of chronic inflammation, but a cut-off level for the infection - sepsis diagnosis needs to be determined [18].

The suitable hemoconcentration is achieved with normalization of serum albumin $(2.86 \%$, although total weight change was 3.5\%). An increase in apoA1 serum levels was observed during the hemodialysis process in the same proportion as albumin; however HDL cholesterol levels increased by 9 times (26,30\%). Hemodialysis also increased serum levels of apolipoprotein-B100 and LDL cholesterol up to 6 times compared with changes in albumin. Based on this information hemodialysis seems to have a powerful capacity for modifying the lipid profile, inducing hepatic secretion of LDL and increasing the amount of cholesterol mobilized by HDL. Therefore, hemoconcentration is not the only factor responsible for lipid profile changes [19].

Normally lipoprotein(a) is fragmented and excreted by the kidneys. During hemodialysis levels of lipoprotein(a) did not change because of their large molecular size, but could be removed by hepatic scavenger receptors of lipoprotein(a) that cleave the apolipoprotein(a) during hemofiltration. However it has not been possible to quantify these processes in RCV calculation and therefore lipoprotein(a) can be used only qualitatively in cardiovascular risk estimation [20].

SAA is an inflammatory marker linked to HDL. It is increased in inflammatory processes and it is not affected by renal function [21]. In our data SAA decreased by approximately $20 \%$ perhaps by clearance of polymers or displacement of SAA due to the changes in HDL and by binding to dialysis membrane. On the other hand, SAA and CRP have similar behavior when evaluating inflammation associated with dialysis process, despite their structural differences.

CRP reached a similar hemoconcentration $(\sim 2 \%)$ as albumin; therefore it is not a useful inflammatory marker of a single hemodialysis session. However, it has been shown that CRP levels are useful in monitoring long term hemodialysis (every 3 months) because CRP median levels are better prognostic marker than a spot CRP value in hemodialysis patients $[22,23]$. In fact, a persistent elevation within a short time period has a worse prognosis than persistent low values or punctual elevations [24].

PTX3 is elevated in advanced chronic kidney disease $[10,25]$. Its protective and deleterious effects are not well known [26]. PTX3 modifies angiogenesis and atherosclerotic lesion development, and participates in extracellular matrix formation. High levels of PTX3 are associated with the presence of vulnerable coronary plaques, cardiovascular disease [25,27] and predict mortality in chronic kidney disease [28]. PTX3 levels are significantly increased during hemodialysis, but it is not clear hemodialysis membranes are responsible for modifying it $[29,30]$. Its decline is related to thrombotic events. In our research PTX3 underwent a striking increase (156\%) during hemodialysis process. PTX3 could be a short-term marker of inflammatory process (acute response), due to a rapid and transient discharge of granules from polymorphonuclear, endothelial and other vessel wall cells related to the biocompatibility of the hemodialysis process itself [31]. At long term, annual decline in levels of PTX3 in hemodialysis patients correlates with increased risk of thrombotic events [32].

End-stagekidney disease patients, even those ESKD patients that are not on dialysis, suffer from a chronic inflammatory state with increase systemic proinflammatory cytokines and oxidizing molecules [33]. This chronic inflammatory state in predialysis end-stage kidney disease patients determines an increased risk of mortality from cardiovascular complications (20\% to $50 \%$ ) which further increases after beginning the renal replacement therapy (especially in hemodialysis) [34]. Vascular access, impurities of dialysate and blood interaction with dialysis membrane causes acute and chronic changes on the inflammatory and vascular response $[35,36]$. The last European Guidelines on cardiovascular Disease recognizes that chronic kidney disease significantly increase cardiovascular risk (High Risk for estimated glomerular filtration rate $=30$ to $60 \mathrm{~mL} / \mathrm{min} / 1.73 \mathrm{~m}^{2}$; Very High Risk in the case of $<30 \mathrm{~mL} /$ $\min / 1.73 \mathrm{~m}^{2}$ ] [1]. Major risk factor of cardiovascular disease does not seem to contribute significantly to this increased risk. However, emerging risk factor of cardiovascular disease like homocysteine, CRP and lipoprotein(a) may explain in part that increased cardiovascular Disease risk due to end-stage kidney disease.

In our research, we estimated cardiovascular risk in healthy controls and end-stage kidney disease, following Adult Treatment Panel-III ${ }^{3}$ and International Atherosclerosis Society [5] guidelines, in order to evaluate changes in risk classification after including emerging risk factor of cardiovascular disease (increased a level of cardiovascular risk if 2 or more emerging risk factor of cardiovascular disease are positives: CRP $>3$ $\mathrm{mg} / \mathrm{L}$, homocysteine $>12 \mu \mathrm{mol} / \mathrm{L}$, lipoprotein(a) $>30 \mathrm{mg} / \mathrm{dL}$, and added a last group of risk to the Adult Treatment Panel-III tables of classical score, called "very high risk"). This change may partially explain the high cardiovascular risk associated to end-stage kidney disease patients and should lead to a more strict control of lipid profile and, more specifically, to try to achieve a LDL-cholesterol target $<70 \mathrm{mg} / \mathrm{dL}$ to reduce the risk of cardiovascular event. However, new guidelines as ATPIV (4) and expert opinions suggest change in strict LDL target. 
Drugs such as statins that are traditionally used to achieve this LDL-target, also have pleiotropic effects that allow the control of undesired cardiovascular events. Moreover, the application of other treatment options, such as the peptidic C3 inhibitor (Cp40) could potentially reduce biomarkers of inflammation during hemodialysis as in animal model [37].

\section{Conclusion}

In this research PTX3 was the best biomarker in evaluating the short-term inflammatory response in hemodialysis and could also have a long-term inverse behaviour to CRP; both molecules could be co-adjuvants markers to calculate the cardiovascular risk score, survival prognosis and biocompatibility of materials in hemodialysis.

Homocysteine, SAA or procalcitonin decreased during hemodialysis because they are hemo-filterable molecules, but could also be released during hemodialysis session; therefore their decline cannot be compared with other small molecules and they always remain above normal values levels.

Computational models of vascular risk, although accepted in clinical practice do not explain the high incidence of cardiovascular morbidity and mortality in hemodialysis patients. The emerging risk factors could justify in part the excess of cardiovascular risk in patients with chronic kidney disease, but further longitudinal studies are required to evaluate these biomarkers with all the factors of the dialysis process (quality of fluid, membranes, frequency and duration of sessions) to evaluate the cardiovascular risk of patients on hemodialysis, and to apply all therapeutic options to decrease this cardiovascular risk.

\section{Acknowledgement}

We thank the staff of the Department of Nephrology and Biochemistry Laboratories for their help in the collection and management of samples.

We thank Paola M. Cota her support in the English style correction.

\section{References}

1. Perk J, DeBacker G, Gohlke H, Graham I, Reiner Z, et al. European Guidelines on cardiovascular disease prevention in clinical practice (version 2012). The Fifth Joint Task Force of the European Society of Cardiology and Other Societies on Cardiovascular Disease Prevention in Clinical Practice (constituted by representatives of nine societies and by invited experts). Eur Heart J. 2012; 33: 1635-1701.

PubMed: https://www.ncbi.nlm.nih.gov/pubmed/22698795

2. Zimmermann J, Herrlinger S, Pruy A, Metzger T, Wanner C. Inflammation enhances cardiovascular risk and mortality in hemodialysis patients. Kidney Int. 1999; 55: 648-658.

PubMed: https://www.ncbi.nlm.nih.gov/pubmed/9987089

3. National Cholesterol Education Program (NCEP) Expert Panel on Detection, Evaluation, and Treatment of High Blood Cholesterol in Adults (Adult Treatment Panel-III). Third Report of the National Cholesterol Education Program (NCEP) Expert Panel on Detection,
Evaluation, and Treatment of High Blood Cholesterol in Adults (ATPIII) final report. Circulation. 2002; 106: 3143-3421.

PubMed: https://www.ncbi.nlm.nih.gov/pubmed/12485966

4. Stone NJU, Robinson J, Lichtenstein AH, BaireyMerz CN, Blum CB, et al. 2013 ACC/AHA Guideline on the Treatment of Blood Cholesterol to Reduce Atherosclerotic Cardiovascular Risk in Adults: A Report of the American College of Cardiology/American Heart Association Task Force on Practice Guidelines. J Am Coll Cardiol. 2014; 63 (25 Pt B): 2889-2934. PubMed: https://www.ncbi.nlm.nih.gov/pubmed/24239923

5. International Atherosclerosis Society (IAS) Harmonized guidelines on prevention os atherosclerotic cardiovascular diseases. 2003; http://www.athero.org/

6. Inoue K, Kodama T, Daida H. Pentraxin 3: a Novel Biomarker for Inflammatory Cardiovascular Disease. Int J Vasc Med. 2012; 2012 657025.

PubMed: https://www.ncbi.nlm.nih.gov/pubmed/22347626

7. Artl A, Marsche G, Sattler W, Malle E. Role of serum amyloid A during metabolism of acute-phase HDL by macrophages. Arterioscler Thromb Vasc Biol. 2000; 20: 763-772.

PubMed: https://www.ncbi.nlm.nih.gov/pubmed/10712402

8. Eklund KK, Niemi K, Kovanen PT. Immune functions of serum amyloid A. Crit Rev Imunol. 2012; 32: 335-348.

PubMed: https://www.ncbi.nlm.nih.gov/pubmed/23237509

9. Belhadj-Tahar $\mathrm{H}$, Coulais $\mathrm{Y}, \mathrm{Tafani} \mathrm{M}$, Bouissou F. Procalcitonin implication in renal cell apoptosis induced by acute pyelonephritis in children. Infect Drug Resist. 2008; 1: 17-20.

PubMed: https://www.ncbi.nlm.nih.gov/pubmed/21694876

10. Lavín-Gómez BA, Palomar-Fontanet $R$, Gago-Fraile $M$, QuintanarLartundo JA, Gómez-Palomo E, et al. Inflammation markers, chronic kidney disease, and renal replacement therapy. Adv Perit Dial. 2011; 27: 33-37.

PubMed: https://www.ncbi.nlm.nih.gov/pubmed/22073825

11. Peralta CA, Jacobs DR, Katz R, Ix JH, Madero M, et al. Association of pulse pressure, arterial elasticity, and endothelial function with kidney function decline among adults with estimated GFR $>60 \mathrm{~mL} / \mathrm{min} / 1.73$ m2: The multi-ethnic study of atherosclerosis (MESA). Am J Kidney Dis. 2012; 59: 41-49.

PubMed: https://www.ncbi.nlm.nih.gov/pubmed/22000727

12. Keller T, Messow CM, Lubos E, Nicaud V, Wild PS, et al. Cystatin C and cardiovascular mortality in patients with coronary artery disease and normal or mildly reduced kidney function: results from the Athero Gene study. Eur Heart J. 2009; 30: 314-320.

PubMed: https://www.ncbi.nlm.nih.gov/pubmed/19153178

13. Malinowska J, Kolodziejczyk J, Olas B. The disturbance of hemostasis induced by hyperhomocysteinemia; the role of antioxidants. Acta Biochim Pol. 2012; 59: 185-194.

PubMed: https://www.ncbi.nlm.nih.gov/pubmed/22577622

14. Wierzbicki AS. Homocysteine and cardiovascular disease: a review of the evidence.Diab Vasc Dis Res. 2007; 4: 143-150.

PubMed: https://www.ncbi.nlm.nih.gov/pubmed/17654449

15. Gómez-Gerique JA, López-Martínez D, Cancelas P, Montoya MT, Porres A. Expresión fenotípica de la $L p(a)$ en niños y adolescentes españoles. Med Clin (Bar). 2000; 114: 13-15.

16. Conti G, Amore A, Chiesa M, Mancuso D, Cirina P, et al. Procalcitonin as a marker of micro-inflammation in hemodialysis. J Nephrol. 2005; 18 : 282-288.

PubMed: https://www.ncbi.nlm.nih.gov/pubmed/16013016

17. Rysz J, Banach M, Cialkowska-Rysz A, Stolarek R, Barylski M, et al. Blood serum levels of IL-2, IL-6, IL-8, TNF-alpha and IL-1 beta in patients 
on maintenance hemodialysis. Cell Mol Immunol. 2006; 3: 151-154. PubMed: https://www.ncbi.nlm.nih.gov/pubmed/16696903

18. Trimarchi $H$, Dicugno $M$, Muryan A, Lombi F, Iturbe L, et al. Pro-calcitonin and inflammation in chronichemodialysis. Medicina (Buenos Aires). 2013; 73: 411-416.

PubMed: https://www.ncbi.nlm.nih.gov/pubmed/24152395

19. Katopodis KP, Koliousi E, Gouva C, Balafa O, Bairaktari E, et al. Acute effect of heparin on lipid parameters in patients on renal replacement therapy. ASAIO J. 2007; 53: 46-49.

PubMed: https://www.ncbi.nlm.nih.gov/pubmed/17237649

20. Lamon-Fava S, Diffenderfer MR, Marcovina SM. Lipoprotein(a) metabolism. Curr Opin Lipidol. 2014; 25: 189-193.

PubMed: https://www.ncbi.nlm.nih.gov/pubmed/24751932

21. Maury CP, Teppo A, Eklund B, Ahonen J. Serum amyloid A protein: a sensitive indicator of renal allograft rejection in humans. Transplantation. 1983; 36: 501-504.

PubMed: https://www.ncbi.nlm.nih.gov/pubmed/6356513

22. Rao $M$, Guo D, Perianayagam $M C$, Tighiouart $H$, Jaber $B L$, et al Plasma interleukin- 6 predicts cardiovascular mortality in hemodialysis patients. Am J Kidney Dis. 2005; 45: 324-333.

PubMed: https://www.ncbi.nlm.nih.gov/pubmed/15685511

23. Snaedal S1, Heimbürger O, Qureshi AR, Danielsson A, Wikström B, et al. Comorbidity and acute clinical events as determinants of C-reactive protein variation in hemodialysis patients: implications for patient survival. Am J Kidney Dis. 2009, 53: 1024-1033.

PubMed: https://www.ncbi.nlm.nih.gov/pubmed/19394732

24. Meuwese CL1, Snaedal S, Halbesma N, Stenvinkel P, Dekker FW, et al. Trimestral variations of C-reactive protein, interleukin- 6 and tumour necrosis factor-alpha are similarly associated with survival in haemodialysis patients. Nephrol Dial Transplant. 2011; 26: 1313-1318. PubMed: https://www.ncbi.nlm.nih.gov/pubmed/20846939

25. Boehme $M$, Kaehne $F$, Kuehne A, Bernhardt W, Schröder $M$, et al. Pentraxin 3 is elevated in haemodialysis patients and is associated with cardiovascular disease. Nephrol Dial Transplant. 2007; 22: 22242229.

PubMed: https://www.ncbi.nlm.nih.gov/pubmed/17496115

26. Cieslik P, Hrycek A. Long PTX3 in the light of its structure, mechanism of action and clinical implications. Autoinmmunity. 2012;45: 119-128. PubMed: https://www.ncbi.nlm.nih.gov/pubmed/21988562

27. Xu Y, Ding X, Zou J, Liu Z, Jiang S, et al. Plasma pentraxin 3 is associated with cardiovascular disease in hemodialysis patients. Ren Fail. 2011; 33: 998-1004.

PubMed: https://www.ncbi.nlm.nih.gov/pubmed/22013933
28. Tong M, Carrero JJ, Qureshi AR, Anderstam B, Heimbürger O, et al. Plasma pentraxin 3 in patients with chronic kidney disease: associations with renal function, protein-energy wasting, cardiovascular disease, and mortality. Clin J Am Soc Nephrol. 2007; 2: 889-897. PubMed: https://www.ncbi.nlm.nih.gov/pubmed/17702732

29. Oldani S, Finazzi S, Botazzi B, Garlanda C, Baldassarre E, et al. Plasma pentraxin-3 as a marker of bioincompatibility in hemodialysis patients. J Nephrol. 2012; 25: 120-126.

PubMed: https://www.ncbi.nlm.nih.gov/pubmed/21725917

30. Sjöberg B, Qureshi AR, Anderstam B, Alvestrand A, Bárány P. Pentraxin 3 , a sensitive early marker of hemodialysis-induced inflammation. Blood Purif. 2012; 34: 290-297.

PubMed: https://www.ncbi.nlm.nih.gov/pubmed/23235124

31. Yamamoto T, Nascimiento MM, Hayashi SY, Qureshi AR, Waniewski J, et al. Changes in circulating biomarkers during a single hemodialysis session. Hemodial Int. 2013; 17: 59-66.

PubMed: https://www.ncbi.nlm.nih.gov/pubmed/22716238

32. Nagai K, Ueda A, Saito C, Zempo-Miyaki A, Yamagata K. Annual decline in pentraxin-3 is a risk of vascular access troubles in hemodialysis patients. Int J Nephrol. 2014; 2014: 297954.

PubMed: https://www.ncbi.nlm.nih.gov/pubmed/25587447

33. Hansson GK, Libby P, Schönbeck U, Yan ZQ. Innate and adaptive immunity in the pathogenesis of atherosclerosis. Circ Res. 2002; 91 281-291.

PubMed: https://www.ncbi.nlm.nih.gov/pubmed/12193460

34. Panichi V, Scatena A, Migliori M, Marchetti V, Paoletti S, et al. Biomarkers of Chronic Inflammatory State in Uremia and Cardiovascular Disease. Int J Inflam. 2012; 360147.

PubMed: https://www.ncbi.nlm.nih.gov/pubmed/22701810

35. Memoli B, Minutolo R, Bisesti V, Postiglione L, Conti A, et al. Changes of serum albumin and $\mathrm{C}$-reactive protein are related to changes of interleukin-6 release by peripheral blood mononuclear cells in hemodialysis patients treated with different membranes. Am J Kidney Dis. 2002; 39: 266-273.

PubMed: https://www.ncbi.nlm.nih.gov/pubmed/11840366

36. Malaponte G, Libra M, Bevelacqua $Y$, Merito $P$, Fatuzzo $P$, et al Inflammatory status in patients with chronic renal failure: The role of PTX3 and pro-inflammatory cytokines. Int Mol Med. 2007; 20: 471-481. PubMed: https://www.ncbi.nlm.nih.gov/pubmed/17786277

37. Reis ES, DeAngelis RA, Chen H, Resuello RR, Ricklin D, Lambris JD. Therapeutic $\mathrm{C} 3$ inhibitor $\mathrm{Cp} 40$ abrogates complement activation induced by modern hemodialysis filters. Immunobiology 2015; 220: 476-482. PubMed: https://www.ncbi.nlm.nih.gov/pubmed/25468722 